\title{
Afro-American Prison Writings: Undoing Race Trouble and Doing Trauma Recovery
}

\section{Ismail Frouini ${ }^{\star}$}

Université Chouaïb Doukkali, El Jadida, Morocco

*Corresponding author: Ismail Frouini, Assistant Professor, Université Chouaïb Doukkali, El Jadida, Morocco, Tel: 0523344447/48; E-mail: ismail.frouini@gmail.com Rec Date: July 11, 2018; Acc Date: September 04, 2018; Pub Date: September 11, 2018

Copyright: (c) 2018 Frouini I. This is an open-access article distributed under the terms of the Creative Commons Attribution License, which permits unrestricted use, distribution, and reproduction in any medium, provided the original author and source are credited.

\begin{abstract}
Race is a discursive-per formative construct. It is the by-product of the knowledge and power relations dynamics. Afro-American dissidents have been once shaped by these power relations and therefore have been subject to these race dynamics. Afro-American prison writings are counter-discourses and testimonies against the atrocities of "white" women during the Civil Rights movement era. Since their historical trauma of enslavement, Afro-American prison writers have left testimonies and diaries about the ordeal of their captivity. The corpus of prison writings documents an important historical period of activism and state repression. This paper investigates the notion of race as a discursive construct and analyses how such discourse perpetuates power relations underlying the oppressed and the oppressor, the dominant and the subaltern in Afro-American prison writings. It also analyses how AfroAmerican prisoners reveal and recover from the trauma they have undergone in the "white" ideological state apparatus, prison. It is premised upon offering a reading from a cultural studies perspective. Both detainees have witnessed the trauma caused by the atrocities committed against colored people by the "white" racists outside and inside prison during the era of Civil Rights Movement.
\end{abstract}

Keywords: Race; Trauma; Class; Afro-American prison writings; Cultural studies

\section{Introduction}

"A feeling of inferiority? No, a feeling of nonexistence. Sin is Negro as virtue is white. F. Fanon, Black Skin, White Masks"

"No one truly knows a nation until one has been inside its jails. A nation should not be judged by how it treats its highest citizens, but its lowest ones. N. Mandela, Long Walk to Freedom"

Afro-American prison writings have been fertile. Its emergence dates back to the early $19^{\text {th }}$ century. Since their enslavements onwards, Afro-American prison writers have rendered prison a fecund space to produce hundreds of testimonies [1,2]. They have attempted to rewrite their history by dint of framing their writings in the past rather than the present. They view that "To articulate the past historically does not mean to recognize it the way it really was. It means to seize hold of a memory as it flashes up at a moment of danger" [3]. This recourse would make a room for the voice the marginalized voices, including the silenced prisoners, to articulate and recover from their trauma. Contemporary novelists like Toni Morrison, Alice Walker and Charles Johnson have taken this advantage to resist and to undo racism as well as to recast dominant historical narratives by means of writing.
Contemporary Afro-American prison writings have become a part of the American culture. They encompass a large body of literary forms that chronicle the cultural trauma and the incarceration experience of Afro-American dissidents. The eclecticism and the prolificness of this genre of literature can be dated from the publication of Malcolm X's Autobiography of Malcolm X, which has a pivotal role in framing the consciousness of Afro-American people. After his assassination in 1965, Afro-American prison writings recognized Malcolm as its political and spiritual leader. For them, Malcolm X's Autobiography is a prison narrative modus operandi. For Malcolm was defiantly and openly able to probe and reveal the entire structure and ideologies of the United States' dominant discourses.

In spite of the fact that colored people in America comprise only $12 \%$ of the entire population, the vast majority of these prisoners are "blacks". The United States vies now only with Russia for highest rates of incarceration internationally. Since the early 1960's, many AfroAmerican prisoners have left hundreds of testimonies. ${ }^{1}$ These prisoners, writers, civil rights activists, anti-war activists, and revolutionists, were imprisoned for political reasons. ${ }^{2}$ The vast majority of these prisoners have become famous prison writers; Eldridge Cleaver and Assata Shaku are no exception. As such, this emerging writing constituted an unprecedented phenomenon. Novels, plays, poems, essays, letters, songs, autobiographies, memoirs, etc. make up this body of literature. Its major concern is to recover from the trauma of enslavement and incarceration as well as to resist the

$1 \quad$ During this period, American prison literature reached its widest audience and had its greatest influence. It is an era which was known as "the long, hot summers." It was also the era of the movement against the Vietnam War, against McCarthyism (Joseph Raymond McCarthy) and against race, class, and gender, and most important the era of Civil Rights Movements.

2 It should be noted that many figures in European and American literatures have been incarcerated as criminals: this includes Socrates, Boethius, Villon, Thomas More, Cervantes, Campanella, Walter Raleigh, Donne, Richard Lovelace, Bunyan, Defoe, Voltaire, Diderot, Thoreau, Melville, Leigh Hunt, Oscar Wilde, Agnes Smedley, Maxim Gorky, Genet, Henry, Bertrand Russell, Chernyeshevsky and Dostoevsky, Stalin and Solzhenitsyn, Christ and the Marquis De Sade [4]. 
racist discourse shaping them. This encompasses The Autobiography of Malcolm X (1965), Eldridge Cleaver's Soul on Ice (1968), George Jackson's Soledad Brother (1970) and Blood in My Eye (1972), Malcolm Braly's On the Yard (1967), Piri Thomas's Seven Long Time (1975) and Down These Mean Streets (1967) James Baldwin, If Beale Street Could Talk (1974) Jack London's 1907 essays "Pinched: A Prison Experience," and "The Pen: Long Days in a County Penitentiary," Wally Lamb's Couldn't Keep It to Myself: Wally Lamb and the Women of York Correctional Institution (Testimonies from our Imprisoned Sisters) (2003) [2], Rubin Carter's the sixteenth round: From Number 1 Contender to Number 45472 (1974), Mumia Abu Jamal's Live from Death Row (1995), Lloyd L. Brown's Iron city (1951) Asha Bandele's a prisoner's wife: A Memoir (1999), Jimmy Santiago Baca's A Place to Stand (2001) and his first collection of poems, Immigrants in Our Own Land appeared in 1979, Angela Y. Davis's Are Prisons Obsolete (2003), John Edgar Wideman's Brothers and Keepers (1984), and others too numerous to mention. Many of Afro-American prison writers were charged with conspiring to "advocate" the overthrow of the regime of McCarthy and advocating communism as well as their active involvement in Civil Rights movement.

Additionally, Afro-American literature in general, and prison literature in particular, is distinguished by its eclectic thematic issues that range from rhetorical practices, myths, folklore, and traditions that derive from the African continent, to the problem of slavery, system of exploitation, incarceration and race they experience in America. Racism occupies a large part of the African American literary history. Before 1960s, Afro-American history and culture were excluded from the writing process of the official version of American history $[4,5]$. They have struggled to subvert the cultural hegemony, or dominance, of the American racist discourse shaping "white" Americans. In their contemporary writings, Afro-American writers have chosen to write about the past. There is an overlap between the present and the past. They have painstakingly evaded and subverted the discourse that casts the multifaceted stories of the colored people's experience as a monolithic story of black experiences. This discourse has, since then, reinforced the hegemonic dominant discourses of the 'white' man.

Many Afro-American activist-writers, mentioned above, participated in the American civil rights movement protests, which got its start in the 1960s; it necessarily aimed at establishing equal civil rights for 'black' American people. This movement addressed issues like racial segregation, abolishing slavery and discrimination. During this period, many Afro-American gained eminence. Included are Malcolm X, Martin Luther King, Victoria Gray, Harriet Tubman, Sojourner Truth, Nina Simone, Mary McLeod, Eldridge Cleaver, Assata Shakur, to name a few. These figures experienced an ordeal trauma because of their color and their courage to speak truth to the "white" power. It is this interrelatedness of "race" and the "trauma of imprisonment" that this paper is at pains to explore by dint of reading $[1,2]$. Both detainees witnessed the trauma caused by the atrocities committed against colored people by the "white" racists outside and inside prison during the era of Civil Rights Movement.

\section{Literature Review}

\section{Race as a discursive construct}

By and large, there is an intersection between the trauma of imprisonment and the trinity of race, gender, and class. In America, the historical formation of race is one of power and subordination; that is, people of color, like Afro-Americans, have occupied structurally subordinate positions [2]. The issue of "race" seems inevitable; AfroAmericans are still victims of the color of their skins pigmentation. Race discrimination is ubiquitous; it is in all state apparatuses (it is in American school, church, bus, public spaces and even in prison). Given their subaltern position vis-à-vis the 'white' subjects, AfroAmericans could not help offer an influential resistance since the whole epistemic violence and hegemonic structures of society are mobilized against them. As such, racism persists by the process of stereotyping. Stereotypical discourse gets to the heart of power relations. In this regard, Bhabha argues that racist stereotypical discourse inscribes a form of govern mentality that is informed by a productive splitting in its constitution of knowledge and exercise of power. Some of its practices recognize the difference of race, culture and history as elaborated by stereotypical knowledge, racial theories, administrative colonial experience, and on that basis, institutionalize a range of political and cultural ideologies that are prejudicial, discriminatory, vestigial, archaic, 'mythical', and, crucially, are recognized as being so [6].

The 'self' has usually recourse to stereotyping its counterpart 'other' to construct its elusive ego. Racism in America, and elsewhere, works accordingly. To give stability to its ego, 'white' Americans go through what Lacan calls 'the mirror stage. They, 'white' Americans, create an illusion of selfhood in an attempt to stop the circulation of signifies. This is what Lacan refers to as the "Imaginary," that is the process of identification that always hinges on inaccessible and unstable self-ego.

From a Foucauldian perspective, "race" is a discursive construct. It is the by-product of the knowledge and power relations. Like other discursive categories of identification (gender, sexuality, identity, ethnicity and so on) race perpetuates power relations. It is the discourse that generates ways of reflecting and talking about of a group of people of certain "color". These ways determine, govern the formation of and contain the "pre-constructed", that is to say, the readymade ideological presuppositions. In so being, the discourse of racism perpetuates the hegemonic power relations and dominance of a group of "colored" people over others.

The rise of cultural studies in 1960s ushered in the theoretical platform from which to analyze how power relations work. Within this context, of particular concern to this paper is Stuart Hall's take on the issue of "race" say of "Black" identity. He replaced much concern on questions of power, knowledge, ideology, hegemony, discourse and representation vis a vis issues like gender, race, class, and language. It is these notions that give cultural studies perspective its distinctive edge. According to Chris Barker, "the cultural studies perspective on race and ethnicity certainly acknowledges the importance of the intersections of race, ethnicity and class" [7]. In cultural studies, "race" is not a stable or a universal "fact"; it is rather shaped by the politics of representation. In so being, the "black/white" skin pigmentation is just a signifier. The attributed meanings, signifies, are dictated by the dominant discourse. They are not fixed; they change in time and space. In line with this argument on the instability of "race," Hall argues in a lecture that race is a floating signifier. It is the discourse that shapes a society that attributes and generates certain meanings on that "race". Hall continues to argue that

"Racism, of course, operates by constructing impassable symbolic boundaries between racially categories and its typically binary system of representation constantly marks and attempts to fix and naturalize the difference between belongingness and otherness" [8,9]. 
'Blackness' of Afro-Americans has many but not fixed or even transcendental signifies. According to Frantz Fanon, 'blackness' connotes "tom-toms, cannibalism, intellectual deficiency, fetishism, racial defects, slave-ships, above all: "Sho' good eatin" [10]. This construction of 'black' subjectivity perpetuates power relations. Americans are subject to this ideology. It is also a kind of domination by means of centering the "white" hegemon and decentering and subalternate 'black' people. It is for these aforementioned reasons that race matters for contemporary Afro-American writers than ever. In so being, Cleaver and Shakur have tried to deconstruct these notions that have dominated and affected American people's thinking and attitude towards people of color inside the American repressive apparatus, prison.

\section{Racism and trauma recovery in soul on ice and Assata}

Contemporary Afro-American prison writings have recourse to past issues of their cultural and historical trauma of enslavement. Despite the world-wide struggles for liberation and freedom, Bruce Franklin views that nowadays the Afro-American vision moves from being colonial victims into international war against colonial enslavement. Such historical and cultural trauma is related to the collective memory of all "Black" people; it shows the trauma caused by slavery, incarceration and the everyday psychological effects of living in a raceconscious America.

The prolificness of the Afro-American prison writings is due to the huge number of the Afro-American prisoners and the traumatic orderliness of the experiences they have had in prison. The vast majority of American prisoners are Afro-American ones. ${ }^{3}$ They have transcribed their ordeal incarceration experience. Franklin views that:

Afro-American prisoners are the largest single group of prisoners, because the situation of Afro-Americans within US society as a whole is reproduced in microcosm within our prisons, and because there that primary fact of Afro-American experience -imprisonment- is shared by other groups and individuals on the bottom of our society, for all these reasons, Afro-American culture has shaped both the form and content of contemporary American prison literature [4]

Given the huge number of Afro-Americans who are behind bars, their literature is growing as well. They have chronicled their lives as subalterns in American society. There is always this interrelatedness of the inside and the outside world. Prison is a microcosm of life outside. Afro-American activists are, to date, subject to relegation and racism inside and outside prison. The accounts that Assata Shakur or Eldridge Cleaver have offered as political prisoners and leaders are akin to those narratives written by Tori Morison or James Baldwin; they share certain thematic issues so far as their writings are concerned.

So far as the Afro-American prisoners' status quo is concerned, it is worth mentioning that Althusser's notion of interpellation is pertinent to the analysis of "blackness". This latter issue is a social construct that is attributed to the ideological and reinforced in/by the repressive state apparatuses. As such, prison serves to interpellate prisoners into subjects to the state ideologies. When transformed into mechanisms of power, these repressive apparatuses would interpellate subjects differently; hence the emergence of new subjectivities. Since power evokes resistance, in the Foucauldian logic, narrating or talking about the trauma of incarceration is a form of resistance per se. To voice their trauma, they have experienced because of their "black race" in the hegemonic American society, Afro-Americans have had recourse to writing. As argued by Barbara Harlow in Resistance Literature, this kind of writings offers resistance to dominant discourse.

The title of Cleaver's winner of the Martin Luther King Jr., Memorial Prize prison memoir Soul on Ice is very telling. It is also oxymoronic in the sense that 'soul' is abstract and intangible which is positioned on an icy tangible substance, ice. This oxymoronic title reveals the contradictory subject and strategic location of the prisoner, say of Cleaver. It also indicates the position of Afro-American subjects in America, as existent but not visible; they are subaltern. The whiteness of the ice is associated with "white" American subjects. The title echoes [11] The Souls of Black Folk. This civil rights leader and political activist have first raised issues that are still debatable for the time being in the Afro-American counter-discourses. "Soul" stands for many things; it is the spirit but, like Afro-Americans, it is invisible. It is also the source of desire and need. The title also suggests the position of this soul which is on ice; so, it will be frozen and will lose its accuracy due to the attractiveness of the whiteness and the coldness of the ice.

Cleaver's publication of his prison memoir came immediately after the assassination of another civil rights leader, Martin Luther King Jr. It is the trauma of the assassination of this latter which has brought into sharp focus the struggle for racial equality. This event, along with other ones, has left a national and cultural trauma in the Afro-American subjects still recurrent in their collective memory. Cleaver's engagement with the "colored" people liberation struggle has been reactive to redeem the lacuna left by death of such a leading figure.

Experiencing and revealing, as a way of healing, what is called posttraumatic stress disorder, Cleaver's prison memoir brings to the fore the binary oppositions (white/ black; men/women; incarceration/ freedom); this binaries denotes that the inmate does not want to socialize and get involved in the community of discourse of the other prisoners. Binaries' marks also the distance, caused by the trauma of imprisonment, between the two - almost antagonistic-parts involved, for "In trauma talk, the dichotomy male-female is aligned with a set of other dichotomies, such as predator-victim and innocent-evil" [12]. Trauma brings into the spotlight these dichotomies to highlight the attitudes of prisoners vis-à-vis other haunting issues. Their prison trauma is attributed to the Manichean discourse shaping the American society. For as argued by Dorothy E. Roberts legal decisions are always inspired by the racist stereotypes of black women:

\section{"The stereotype of the aggressive, 'macho' Black male legitimates the massive incarceration of young Black women" [13].}

In his prison memoir, Cleaver highlights the need of the AfroAmericans to be fully aware of and construe their idiosyncratic mode of existence; hence being proud of their Afro-Americans. Cleaver says "I began to form a concept of what it meant to be black in white America"[1]. In raising this consciousness, Cleaver's memoir is almost theorizing, unlike Shakur's, which is about her and other AfroAmerican's lives. Cleaver keeps castigating other Afro-Americans, James Baldwin, for instance, who are enticed by the "white" American standards of life. As such, Cleaver is trying to dismantle such anomic discourse that shapes the lives and the mind-sets of "colored people". As a leader and intellectual, Cleaver struggles first to dismantle the dominant feeling of many Afro-Americans, " $A$ feeling of inferiority?

3 In 2001 national statistics demonstrated that African Americans represented 46.3\% of the total prison population. For more on this, see Cynthia P [8,9]. 
Page 4 of 6

No, A feeling of nonexistence. Sin is Negro as virtue is white" [10]. Undoubtedly, such feeling is caused by the historical and cultural trauma they have undergone since slavery. As for the identity crisis of the Afro-American subjects, Shakur echoes and even goes further to supplement Cleaver in his castration of the Afro-American white man's lackeys, who are passively disciplined within the "white" women's "order of discourse". In this vain, Shakur refers to the example "of the sisters at Rikers. They were so brainwashed they thought a white lawyer, any white lawyer, was better than a Black lawyer" [14]. Ultimately, they both dismantle this self-racializing discourse.

Basically, Eldridge Cleaver's memoir Soul on Ice contains his political commentaries and his cultural analyses of the American society. The memoir opens up with a historical date "nineteen fiftyfour". This indicates that Cleaver is going to foreground the kind of historical consciousness that has been underlying the Afro-American uprising and demand for civil rights in the 1960s United States of America. This opening indicates that making a collective memory of the Afro-American culture and history is central to Cleaver and his Afro-American contemporaries, Shakur included. The antagonistic binary and the "monolithic myth of white supremacy and black Inferiority" [1] frames also the most repeated words of the memoir. This repetition, as argued by Judith Butler, "is associated with the representation of the past, and hence, it indicates a way in which the ego fails to inhabit present time" (Butler 273) for this repetition shows the trauma incarceration and demonstrates the survivor's or victim's inability to accept and put up with the present which is framed by such ongoing discursive practices of "racism".

In the Afro-American context, celebrating 'blackness' or AfroAmericanos is a means of resistance, because some 'white' American racists supplement the thesis that "the race problem in America cannot be settled until all traces of black race are eliminated" [1]. As argued by Mikhail Bakhtin, the discourse of racism is a kind of double-voiced discourse, to admit and resist. Despite the fact that racism is a haunting issue in American prisons which perpetuates the power relations of dominance and docility, Afro-American prisoners utilize it race as a counter discourse to articulate their subject positions.

Cleaver's discourse on the incarcerated Afro-American men offers the aforementioned strategy to examine ways of speaking and constructing "blackness". Moreover, it also offers the possibility of analyzing the subject positions available and deployed during his imprisonment. The analysis of how Cleaver, or other Afro-American prisoners, represents himself as a "male" subject depicts his ability to cope with the trauma of incarceration, in relation with other "black" prisoners. Colored people, following the thread line of the arguments of Cleaver, want to live in peace evoking neither the 'black' sense difference nor the "white" one. Given their powerless subject positions, the Afro-American prisoners, lacking power, find it difficult to create an intercultural, borrowing from Bhabha, third space of enunciation. Given that this latter is a matter of power relations, their subalternity sustains. Thus, the trauma of racism and segregation is sharply accentuated in prison.

The potency of Cleaver's black consciousness is that he is aware that it's "American capitalism that deserved all hatred and contempt that I felt for it in my heart" [1]. The blame, however, is not to put on all Americans, for he believes that "there is in America today a "generation of white youth that is truly worthy of black man's respect" [1]. He has correctly identified the enemy as the capitalist system, the system which oppresses all subaltern people in the United States and around the world.
In Cleaver's discourse, the "colored" and "white" subjects cannot reconcile except by sex and rape. The interrelatedness of race, gender and sexuality and power relations in prison in Soul on Ice is very telling. This indicates the role "masculinity" plays in relation to race and incarceration in the 'white' American prisons. The subaltern subject position of "colored" Americans sharply intensifies the relations of power that shape them inside and outside the American repressive state apparatus, prison. The enmeshment of race and class with gender relations and sexuality is predicated upon an ongoing 'black/white' Manichaean relationship. "We shall have our manhood. We shall have it or the earth will be leveled by our attempt to gain it" [1]. Having this subjectivity would allow Afro-Americans to have agency. This is an appeal which he has made for all Afro-American subjects to be autonomous to defend their case.

As mentioned before, the discourse of racism is twofold. In so being, Dubois does not allow what he calls "race pride" to blind him to the obvious shortcomings of his "black" women. In a like manner, Eldridge Cleaver acknowledges the inaccuracy of some Afro-American subjects. Included is James Baldwin, who is castigated for his apotheosis of the "white" women. On this ambivalent subject position, Du Bois asserts that:

"I should be the last to deny the patent weaknesses and shortcomings of the Negro people; I should be the last to withhold sympathy from the white South in its efforts to solve its intricate social problems. I freely acknowledge that ... undeveloped people should be ruled by the best of their stronger and better neighbors for their own good" [11].

Afro-American prison writings have brought into sharp focus the inter-relatedness of race and class as two theoretical frames for understanding how power relations are foregrounded. However, the two, race and class, are central to the construction of what is called "black" national consciousness and identity as well. Consciousness is primarily premised upon such self-assertion; that is to say, conceiving of the discourse "blackness" as a construct rather than natural. Cleaver says that "I decided to get myself a pin-up girl to paste on the wall of my cell... Don't you know we have a rule against pasting up pictures on the wall? Get yourself a colored girl for a pinup-no white women-I'll let it stay up" [1]. In this exchange between Cleaver and a "white" prison guard, it is worth highlighting Althusser's thesis that such view or strategic location is attributed to the state apparatuses. Interpellated as subjects of the hegemonic American discourse, prison guards perpetuate the discourse of racism by not allowing Cleaver not to have a "white" pinup.

Shakur's prison memoir, Assata: An Autobiography (1987) narrates in retrospect the ordeal prison experience of an Afro-American female activist and Black Panther leader: Assata Shakur. Shakur, the title of this prison memoir, is the eponymous character in this memoir. In this prison memoir, Shakur puts together her prison experience and her early golden life as a free Afro- American child. At the level of narratology, Shakur makes many ruptures in telling her traumatic prison experience; she introduces the reader into the trauma of her imprisonment then takes the reader back to her golden age of childhood. However, Assata is not about self-victimization, but it is a testimony and narrative of trauma recovery and self-affirmation. To recover and do away with racism and traumatic experience, Shakur inserts some passages of and about the free Shakur. Since there is no way to defeat the forgetting that comes with the recovery from trauma, and the most powerful and subtle forms of forgetting are narrative 
memory. Narrative memory, which is the core of historical representation transforms the past as a condition of retaining it [15].

Prisoners offer resistance to the prison oppressive techniques of traumatizing the prisoners. Writing is a way of recovery from trauma, following Roth. Writing about her trauma, Shakur intends to bear witness and revive the Afro-American memory of a cultural trauma. The language she uses to speak about her trauma is "somehow literary: A language that defies, even as it claims, our understanding” [16]. It evokes the reader's imagination of the status quo.

Shakur and other Afro-American female prisoners are subjected to racism. Other aspects of racism of the Afro-American subjects in general and Afro-American female prisoners in particular are the negligence of prisoners. Shakur, for instance, is subject to this negligence, she has "been awaiting trial for two and one-half years" [14]. As such, Willingham notes that "One of the common themes in black women's prison writings is the abandonment and neglect experienced once women are incarcerated" [17]. Shakur has been subject to this procrastination and neglect while in the American repressive apparatus, waiting for the trial. Instead of recovering from the trauma of their imprisonment, this traumatizing strategy exacerbates their traumatic and subaltern status quo.

Post-1960s America was characterized by a collective trauma and memory, inspired by the "colored" people uprising in what is called Civil Rights movement. This period was one of the turbulent decades in the American history. Under such conditions, and given her strategic location and position, as a subaltern, oppressed, female AfroAmerican prisoner of conscience, Shakur speaks for the other oppressed who have been locked by the lawless; Handcuffed by the haters. Gagged by the greedy. For whom wall is just a wall and nothing more at all. It can be broken down [14].

Shakur's Manichean thinking shows to what extent she is traumatized in prison. She echoes Cleaver's take on the issue of trauma. As this stanza reads, the use of binary opposition shows the stand Shakur takes vis-à-vis what is supposedly their counterpart, "white" Americans. In this regard, Shakur's thought is framed by that discourse that the "white" men's "culture comes to be associated, often aggressively, with the nation or the state; this differentiates "us" from "them," almost always with some degree of xenophobia" [18]. Falling in this trap of dichotomizing the pluralistic American society, Shakur, like Cleaver, bespeaks how Afro-American cultures, as a source of identity, is conceived of with such degree of xenophobia. Moreover, it indicates that these binaries perpetuate power relations in prison, since the "torturer" or the oppressor is "lawless," "hater" and "greedy" in Shakur's terminology. This also embodies that Afro-American subjects are threatening "others".

In the political discourse of the United States of America, notable Afro-American freedom-fighters, like Assata Shakur, Mumia AbuJamal, Malcolm X, Eldridge Cleaver and Leonard Peltier, are represented and constructed as "criminals" who deserve either to be executed or to be sentenced to life imprisonment. It is for this reason that "they put me in solitary confinement" [1]. Isolation and ostracism, which are the main sources of these prisoners' trauma, are means of carceral transformation. While in the "white" man's repressive apparatus, Folsom Prison, Cleaver recovers from his trauma by intensive reading in his cell or in solitary confinement. Pervasive sickness of racism and the traumatic effect of this on the colored people make the loci of Cleaver in this memoir. At that time, 1960s across 1970s, when the Afro-American liberation movements were at their heydays, the cryptic discourse that the "white" woman has circulated on the "blacks" was the association of the Afro-American case with "terrorism". The American "media association of the name Joanne Chesimard with "terrorism in thousands of New Jersey articles has produced the intended result that over $70 \%$ of the population think Assata is guilty before she even comes to trial" [14]. Thus, AfroAmerican freedom-fighters are constructed as terrorists. Such discourses delimit a form of "regime of truth" that Afro-Americans are "terrorist".

The issue of racism is overwhelmingly challenging for AfroAmerican subjects, It is embedded in the structures of the society and in its apparatuses as well. Capitalist American "regime of truth" has shaped and manipulated all the discourses on "the criminal" AfroAmerican subjects. It has also mobilized its ideological and repressive state apparatuses to perpetuate its dominance. Going back to Bhabha's argument above, othering is also a means of racialization. Shakur says that "She's wild; she's flamboyant and eccentric; she might scare the jury" [2]. Shakur is viewed as wild, flamboyant and eccentric to influence and shape the way in which the "jury" would look at her. Whilst in prison, the situation of these prisoners is exacerbating, for being constructed as "terrorists" and "criminals" would legitimatize all the cruel methods of traumatizing the "colored" people. "Every other week i was hearing about somebody disappearing. Police repression had come down so hard on the Black movement that it seemed as if the entire Black community was on the FBI's Most Wanted list" [2]. AfroAmericans have been considered to be the communist enemies of the capitalist American democracy. Disappearing is a kind of systemic violence exerted on the Afro-American subjects to discipline them and interpellate them accordingly.

The above narratives show the interrelatedness of the inside world of prison with the outside one. The inside is more irritating, for it emphasizes the power relations underlying this apparatus. Prison circulates power. This disciplinary power, in Foucauldian terminology, is diffused throughout social spaces. The continuum of racism within prison and outside prison is what Michel Foucault refers to as "the carceral" $[19,20]$. Prison perpetuates racist relations. That's why "When I got ready to go to sleep the first night, I asked the guard to turn off the lights. She refused. "I can't see you if the light isn't on" $[2,14]$. This carceral network "'naturalizes' the legal power to punish, as it 'legalizes' the technical power to discipline" [19,20]. Once there, prisoners become subject to all methods of traumatic incarceration and isolation, which are, in Foucauldian terminology, agents of carceral transformation.

\section{Discussion and Conclusion}

In a nutshell, these Afro-American prison writings show the intersection of race and trauma of incarceration in the American prison, as a repressive state apparatus. Cleaver and Shakur in their prison writings show how power relations work and perpetuate as well. In this repressive state apparatus, the trauma of the prisoners presents itself as another a body of collective and past memory which they would recover from. Power relations work through the trinity of gender, race and class. Amongst other factors, these are the main ones that circulate power relations in every space. These working-class prisoners, felons, who are separated from compliant and docile subjects, were imprisoned precisely "for more "sophisticated" crimes than the average state prisoner. But the majority were poor, Black, or Third World" [14]. Incarceration is also class-inspired: the lower, the more traumatizing. Such trauma is instigated by the carceral regime 
Page 6 of 6

that naturalizes incarceration and racialization. "Blackness" and "whiteness" are constructs and man-made; they have no either ontological or epistemological stability or distinction. Therefore "all American cultures are involved in one another; none is single and pure, all are hybrid, heterogeneous, extraordinarily differentiated, and monolithic" [18].

Despite the interaction and the intersection of gender, class, and race ideologies, Afro-American prisoners have acquired what has been termed a "multiple consciousness" [21]. This consciousness is acquired out of their experience that grants them a multifaceted view of liberation and humanization and leads them to offer a multidimensional critique of oppression and segregation. As these narratives show, such consciousness has helped Afro-American prisoners to recover from their historical trauma and dismantle the racist discourse shaping them in the "white" American repressive state apparatuses. The abovementioned trilogy (identity, race, class) is a discursive construct. It is attributed to the academic "knowledge", say discourse, which perpetuates power relations by such human classification and dichotomization as well. Race is one of the major concepts that make great classification within societies in the American state apparatuses. It is believed that 'white' color is superior to 'black' one. However, being 'black' or 'white' does not guarantee that you are supremacist. For there is no center or transcendental signified that ascribes supremacy, purity, and infallibility of a race over others. Such consciousness is also meant to generate a political ideology and discourse of resistance. Going back to the Foucauldian premise [22] "where there is power, there is resistance" such overuse of power which is attributed to the biological race is challenged. Afro-American prisoners are also agents of reform and change. In so being, "Blackness" has been appropriated as a form of resistance.

The narratives above contend that the white ethnic "regime of truth" is to legitimize and enforce the discursive formation of the "white" supremacy [23]. The politics of racism sometimes, as argued by Bakhtin, serves as a double-voiced discourse. It juxtaposes both the Afro-American voice of oppression and the voice of liberation. In their (prison) writings, Shakur and Cleaver appropriate and weapons "race" trouble and give it other meanings, say signified [24]. This supports Halls thesis that "race" is just a floating signifier. The so-called "black" race could be therefore a signified-- at least for the colored people-- of cultural identity that defines them as a nation. Such appropriation has helped them deconstruct and dismantle the race trouble and simultaneously it has helped them recover from their trauma of incarceration [25].

\section{Conflicts of Interest}

There are no conflicts.

\section{References}

1. Cleaver E (1992) Soul on ice. McGraw-Hill, New York.

2. Assata S (1987) Assata: An autobiography. III. L. Hill, Chicago.

3. Benjamin W (1968) Illuminations: Essays and reflections. Schocken, New York.

4. Franklin HB (1977) The literature of the American prison. The Massachusetts Review, United States.

5. Tyson L (2006) African American criticism critical theory today. (2nd edn), Routledge, London.

6. Bhabha H (1994) The location of culture. Routledge, London.

7. Barker, Chris (2005) Cultural studies: Theory and practice, Sage Publications, London pp: 1-424.

8. Hall S (1996) New ethnicities: Critical dialogues in cultural studies. Routledge, New York.

9. Hall S (2002) Race: The floating signifier. MA: Media Education Foundation, Northampton.

10. Fanon F (1986) Black Skin, white masks. Pluto Press, London.

11. Du Bois WEB (2007) The souls of black folk. Oxford University Press, New York.

12. Lamb S (1999) New versions of victims: Feminists struggle with the concept. New York university press, New York.

13. Levit N (2000) The gender line: Men, women, and the law. New York University Press, New York.

14. Assata S (1977) Women against prison, Assata Shakur on Trial. Off Our Backs 7: 5.

15. Michael SR (2012) Memory, trauma, and history: Essays on living with the past. Columbia University Press, New York.

16. Caruth C (1996) Unclaimed experience: Trauma, narrative and history. John Hopkins University Press, Baltimore.

17. Breea CW (2011) Black women's prison narratives and the intersection of race, gender, and sexuality in US prisons. Critical Survey 23: 55-56.

18. Edward WS (1994) Culture and imperialism. Vintage, London.

19. Foucault M (1975) Discipline and punish: The birth of the prison. Vintage Books, New York.

20. Foucault M (1978) The history of sexuality: An Introduction. Pantheon Books, New York.

21. Harvell, VG (2010) Afrocentric humanism and African American women's humanizing activism. Journal of Black Studies 40: 1052-1074.

22. Althusser L (1971) Ideology and ideological state apparatuses (Notes towards an investigation). Lenin and Philosophy and other essay. Monthly Review Press, New York.

23. Judith B (1990) The pleasures of repetition, pleasure beyond the pleasure principle. Yale University Press, New Haven.

24. Honoré-Collins Cynthia P (2005) The impact of African American incarceration on African American children in the child welfare system race, gender, and class in public policy, planning, and administration 20 : 107-118.

25. Connor O, Patricia E (2001) The prison cage as home for African American men. Journal of African American Men 6: 71-86. 